\title{
Effect of cooking on proteinase inhibitors of Dolichos lablab bean (Dolichos lablab perpureus L.)
}

\author{
V.R. DEVARAJ \& N.H. MANJUNATH* \\ Department of Chemistry, Bangalore University, Central College, Bangalore 560001 , India \\ (*athor for correspondence)
}

Received 5 May 1993; accepted in revised form 15 May 1995

Key words: Dolichos lablab perpureus L., Antinutritional factors, Proteinase inhibitors, Trypsin inhibitory activity, Chymotrypsin inhibitory activity, Effect of cooking, Effect of heat, Varietal analysis.

\begin{abstract}
Proteinase inhibitory activity in ten different varieties of Dolichos lablab perpureus. L. was determined. All the varieties tested exhibited appreciable level of proteinase inhibitory activity (PIA). The trypsin inhibitory activity (TIA) (Mean:20170 TIU/g) was relatively higher than the chymotrypsin inhibitory activity (CIA) (Mean: $15380 \mathrm{CIU} / \mathrm{g}$ ). Effect of temperature and cooking on PIA was studied. The nature of cooking medium and duration of cooking had profound effect on the PIA. The dry fried seeds lost their PIA very rapidly ( $91 \%$ in 20 min). Seeds cooked in slightly alkaline medium lost their PIA quickly ( $89 \%$ in $30 \mathrm{~min}$ ) compared to those cooked in acidic $(80 \%$ in $30 \mathrm{~min})$ and neutral $\mathrm{pH}(83 \%$ in $30 \mathrm{~min})$. The PIA in green pods was also determined and they had only one third of the PIA ( $8200 \mathrm{TIU} / \mathrm{g}$ and $8125 \mathrm{CIU} / \mathrm{g})$ found in the dry seeds.
\end{abstract}

\section{Introduction}

Protein proteinase inhibitors are widely distributed in plants and microbial systems [1-3]. Since early 1940s, the plant inhibitors have been extensively studied as antinutritional factors due to the potential adverse effects they produce on human and animal intestinal tracts $[1,2,4]$. The legumes have provided large amount of protein in the human diet. However, their use as sole sources of protein has been subdued due to the presence of the antinutritional factors, in particular, the proteinase inhibitors. Nevertheless, there has been a remarkable improvement in the nutritional quality of legume foods due to various treatment methods $[5,6]$.

Dolichos lablab perpureus is extensively grown in India [7]. In South India, the seeds are consumed as whole seeds as well as split pulse. Generally, the seeds are cooked with spices or dry fried. The proteinase inhibitors of Dolichos lablab perpureus have been partially characterized $[8,9]$ and have been shown to inhibit human trypsin and chymotrypsin $[4,10]$. Many proteinase inhibitors are resistant to heat and acidic $\mathrm{pH}$ [11-13]. This heat stability of proteinase inhibitors and their proved adverse effects on digestive tracts prompted us to study the effect of cooking on proteinase inhibitors of Dolichos lablab perpureus seeds. 
Screening of different varieties of Dolichos lablab perpureus has also been carried out to ascertain the variation in the PIA level with reference to the genetic variation.

\section{Materials and methods}

Samples. Different varieties of field bean seeds were procured from Germplasm Collection, Pulse Management Department, University of Agricultural Science, G.K.V.K., Bangalore 65, India.

Chemicals. Casein (technical grade), trypsin (IX crystalline, salt free, DPCCtreated type IX), chymotrypsin ( $3 \mathrm{X}$ crystallised, salt free) were purchased from Sigma Chemical (St Louis, USA). All other chemicals were of analytical grade.

Frying. Dry seeds were fried on a frying pan for 20-25 min.

Cooking. $2 \mathrm{~g}$ seeds were cooked in a boiling water bath $\left(97^{\circ} \mathrm{C}\right)$ for different time intervals $-10,20,30$ and $60 \mathrm{~min}$ in $50 \mathrm{ml}$ water of varying $\mathrm{pH}(5.7,7.0,8.6)$ and salt ( $\mathrm{pH} 7.0$ with $0.2 \mathrm{M} \mathrm{NaCl}$ ). The $\mathrm{pH}$ of the water in each case was adjusted by using dilute acetic acid or ammonium hydroxide.

Heat treatments. $10 \mathrm{ml}$ aliquots of inhibitor extract from dry seeds were adjusted to acid (3.0), alkaline (12.0) and neutral (7.0) $\mathrm{pH}$ with dilute acetic acid and ammonium hydroxide. The $\mathrm{pH}$ adjusted aliquots were subjected to heating at different temperatures ranging from 30 to $90^{\circ} \mathrm{C}$ for $30 \mathrm{~min}$, the extracts were then cooled in ice-bath and residual TIA and CIA were determined after adjusting the $\mathrm{pH}$ to 7.6 .

Extraction of proteinase inhibitors. Dry seeds and fried seeds: whole seeds were ground to fine powder and defatted with acetone. The defatted flour was extracted with $100 \mathrm{mM}$ phosphate buffer $\mathrm{pH} 7.6$ for 4 hours at $4{ }^{\circ} \mathrm{C}$ by taking flour to buffer ratio of $1: 10(\mathrm{w} / \mathrm{v})$. The suspension was centrifuged for $30 \mathrm{~min}$ at $10,000 \mathrm{rpm}$ at $4^{\circ} \mathrm{C}$ and the clear supernatant was used for estimation of PIA and protein.

Cooked seeds: seeds cooked for different time intervals were homogenised with phosphate buffer in an all glass pottor Elvejhem type homogenizer. The homogenate was centrifuged at $10,000 \mathrm{rpm}$ for $30 \mathrm{~min}$ and the supernatant was used for estimation of PIA and protein.

Assay of proteinases. The trypsin and chymotrypsin activities were determined by the caseinolytic method $[14,15] .1 \mathrm{ml}$ of phosphate buffer, $\mathrm{pH} 7.6$ containing $25 \mu \mathrm{g}$ of trypsin or $20 \mu \mathrm{g}$ of chymotrypsin was incubated at $37^{\circ} \mathrm{C}$ with $1.0 \mathrm{~mL} 1 \%$ casein in phosphate buffer or borate buffer, $\mathrm{pH} 7.6$ for 20 and $10 \mathrm{~min}$ respectively. The reaction was arrested by adding $3 \mathrm{ml}$ of trichloroacetic 
acid. The suspension was filtered and the absorbance of the filtrate was read at 280 and $275 \mathrm{~nm}$ for trypsin and chymotrypsin respectively in UV-VIS specord (Carl Zeiss). Estimation of TIA and CIA was carried out by incubating different aliquots of the inhibitor extract with $25 \mu \mathrm{g}$ of trypsin and $20 \mu \mathrm{g}$ of chymotrypsin for $15 \mathrm{~min}$, and the residual activities of the enzymes were determined by the caseinolytic method.

Units. One unit of trypsin and chymotrypsin is defined as 0.01 increase in the absorbance at $280 \mathrm{~nm}$ and $275 \mathrm{~nm}$ respectively under the assay condition. The trypsin inhibitory units (TIUs) and chymotrypsin inhibitory units (CIs) are the number of trypsin and chymotrypsin units inhibited under the same assay conditions.

\section{Results and discussion}

Proteinase inhibitory activity $(P I A)$ in different varieties of Dolichos lablab perpureus. The PIA estimated in different varieties of Dolichos lablab bean seeds are summarized in the Table 1 . All the varieties tested had good amount of PIA. The level of TIA was marginally higher than the level of CIA. These PIAs are comparable to those of red kidney bean (Phaseolus vulgaris) and horse gram (Macrotyloma uniflorum) $[11,16]$. However, the levels were higher than those reported for finger millet (Eleusine Coracana) [13]. The variation in the PIA levels in different varieties may be due to the genetic variation in the varieties as observed in the case of finger millet (Eleusine coracana) and pearl millet (Pennisetum typhoideum) $[13,17]$.

Table 1. P'roteinase inhibitory activities in Dolichos lablab varieties

\begin{tabular}{rllrrr}
\hline & Variety & $\begin{array}{l}\text { Seed } \\
\text { colour }\end{array}$ & TIU/g & CIU/g & $\begin{array}{l}\text { Soluble } \\
\text { protein } \\
\text { mg/g }\end{array}$ \\
\hline 1. & HA-3 & Brown & 23,000 & 20,650 & 146.0 \\
2. & Maniavare & Brown & 22,750 & 19,100 & 133.0 \\
3. & Race-21 & Black & 27,700 & 16,300 & 74.0 \\
4. & Race-31 & Cream & 19,200 & 10,800 & 73.0 \\
5. & Race-42 & Reddish & 11,750 & 8,000 & 177.0 \\
& & Brown & & & \\
6. & Race-54 & Black & 11,800 & 11,150 & 175.0 \\
7. & Race-62 & Brown & 23,900 & 16,300 & 190.0 \\
8. & Typicus & Brown & 26,900 & 24,300 & 167.0 \\
9. & Typicus & Black & 13,700 & 11,250 & 120.0 \\
10. & G.K. avare & Cream & 21,000 & 16,000 & 130.0 \\
& Average & & 20,170 & 15,380 & 138.0 \\
11. & Green pods of & & 8,200 & 8,100 & 102.0 \\
& maniavare & & & & \\
\hline
\end{tabular}


The Dolichos lablab perpureus typicus which is a garden variety, whose pods are mainly consumed as vegetable had highest TIA and CIA. The lower levels of PIA in green seeds (maniavare) is in conformity with the observation of Ambe \& Sohanie [18], that proteinase inhibitors are synthesized at later stages of the seed development, and that their physiological role is as storage proteins. It is noteworthy that the newly developed variety (HA-3) which is replacing the traditional varieties for season independent cultivation and higher yields, exhibited higher PIA than the traditional ones.

Effect of heat and cooking on proteinase inhibitors of Dolichos lablab perpureus. Effect of heat on proteinase inhibitors in crude extracts showed their stability to heat at acid and neutral $\mathrm{pH}$ and their relative lability at alkaline $\mathrm{pH}$ (Table 2).

The effect of heat treatment on proteinase inhibitors in crude extracts are entirely different from cooking conditions, involving whole seeds. Hence, it was imperative to study the effect of cooking on PIA on whole seeds. Table 3 shows the effect of cooking on proteinase inhibitors of Dolichos lablab perpureus. The PIA was completely lost by $60 \mathrm{~min}$ cooking in all the cooking conditions chosen. Cooking for $10 \mathrm{~min}$ had moderate effect on PIA except in $\mathrm{pH} 8.5(40 \%$ loss of TIA). Nearly $50 \%$ of PIA was lost after $20 \mathrm{~min}$ of cooking in all the chosen conditions. The residual CIA and TIA after $30 \mathrm{~min}$ cooking appeared to be the same in all the conditions (16-19\%). Comparison of 30 min heating data with that of $30 \mathrm{~min}$ cooking indicated that PIA is more rapidly lost in crude extracts than in whole seeds except in acidic $\mathrm{pH}$ where both CIA and TIA were highly stable ( $80 \%$ CIA, and $97 \%$ TIA).

The dry frying for $20 \mathrm{~min}$ resulted in remarkable denaturation of PIA. Though dry frying, appeared to be effective in denaturing the proteins inhibitors, the soluble protein content was very low when compared to $30 \mathrm{~min}$ cooked seeds which are ideal for consumption (Table 3).

Although cooking methods seem to be irrational in rural parts of South

Table 2. Effect of temperature on Dolichos lablab inhibitors

\begin{tabular}{|c|c|c|c|c|c|c|c|}
\hline \multirow{3}{*}{$\begin{array}{l}\text { Temperature } \\
\left({ }^{\circ} \mathrm{C}\right)\end{array}$} & \multicolumn{4}{|c|}{ Inhibitory activity } & & & \\
\hline & \multicolumn{3}{|c|}{ TIA $(\%)$} & \multirow[b]{2}{*}{12.0} & \multicolumn{3}{|c|}{$\operatorname{CIA}(\%)$} \\
\hline & $\mathrm{pH}$ & 3.0 & 7.0 & & 3.0 & 7.0 & 12 \\
\hline 25 & & 100.0 & 100.0 & 100.0 & 100.0 & 100.0 & 100.0 \\
\hline 40 & & 100.0 & 92.8 & 97.4 & 94.4 & 98.5 & 81.5 \\
\hline 50 & & 100.0 & 89.2 & 82.7 & 90.7 & 96.8 & 67.6 \\
\hline 60 & & 97.0 & 88.6 & 12.8 & 91.6 & 95.6 & 17.6 \\
\hline 70 & & 97.0 & 90.2 & 7.7 & 86.1 & 94.6 & 12.0 \\
\hline 80 & & 97.0 & 68.0 & 6.9 & 88.8 & 80.1 & 15.7 \\
\hline 97 & & 97.4 & 8.2 & 7.7 & 80.5 & 4.66 & 16.6 \\
\hline
\end{tabular}

$\mathrm{CIA}=$ chymotrypsin inhibitory activity; TIA $=$ trypsin inhibitory activity. 
Table 3. Effect of cooking on proteinase inhibitory activity of Dolichos lablab perpureus $\mathrm{L}$. seeds

\begin{tabular}{lllllll}
\hline $\begin{array}{l}\text { Duration } \\
\text { of cooking }\end{array}$ & \multicolumn{3}{l}{ Cooking conditions } & Dry frying \\
\cline { 2 - 5 } & $\mathrm{pH}$ & 7.0 & 5.7 & 8.5 & $\begin{array}{l}7.0 \\
8 \mathrm{NaCl}\end{array}$ & $\begin{array}{l}7.0 \\
\end{array}$ \\
\hline
\end{tabular}

Trypsin inhibitory units

Dry seeds

22000

$10 \mathrm{~min} \quad 20460$

$20 \mathrm{~min} \quad 10400$

$30 \mathrm{~min} \quad 3840$

$\begin{array}{rrr}21340 & 13300 & 21560 \\ 11440 & 6760 & 11336 \\ 4240 & 2518 & 4204 \\ 000 & 000 & 000\end{array}$

1992

$60 \mathrm{~min}$

000

000

Chymotrypsin inhibitory units

Dry seeds $\quad 20500$

$10 \mathrm{~min} \quad 20000$

$20 \mathrm{~min} \quad 12400$

$30 \mathrm{~min}$

4345

$60 \mathrm{~min}$

000

$\begin{array}{rrr}17940 & 15200 & 13060 \\ 11360 & 9424 & 8085 \\ 3900 & 3308 & 2834 \\ 000 & 000 & 000\end{array}$

1503

Soluble protein (in $\mathrm{mg}$ )

Dry seeds

144

$10 \mathrm{~min}$

$20 \mathrm{~min}$

133
109

$30 \mathrm{~min}$

$60 \mathrm{~min}$

31

100

India, these results indicate that they are effective in destruction of antinutritional factors (PI) in the Dolichos lablab perpureus. It can be surmised that nature of cooking medium such as $\mathrm{pH}$ of water, salt content and duration of cooking medium such as $\mathrm{pH}$ of water, salt content and duration of cooking are important factors to be considered for preparation of dishes of this bean, as these conditions vary depending on the geographical locations.

\section{Acknowledgements}

The authors wish to thank Dr Veeresh, Department of Pulse Management, G.K.V.K., Bangalore, for the supply of samples. They also express their thanks to Prof. P.S. Veerabhadrappa, Department of Chemistry, Central College for his kind co-operation. V.R.D. is thankful to Bangalore University for the Research Assistantship.

\section{References}

1. Laskowski Jr M, Kato I (1980) Protein inhibitors of proteinases. Ann Rev Biochem 49: 593-626. 
2. Liener IE (1979) Nutritional significance of plant protein inhibitors. Proc Nutr Soc 38: 109-118.

3. Richardson $\mathrm{M}$ (1977) The protein inhibitors of plant and microorganisms. Phytochem 16: 159-169.

4. Prabhu KS, Saldhana K, Pattabiraman TN (1984) Natural enzyme inhibitors: A comparative study of the action of legume inhibitors on bovine and human pancreatic proteinases. I Sci Food Agric 35: 314-321.

5. Friedman M, Gumbman R (1986) Nutritional improvement of legume proteins through disulfide interchange. In: Friedman $M(\mathrm{ed})$, Nutritional and toxicological significance of enzyme inhibitors in foods. New York: Plenum Press, pp 357-390.

6. Rackis JJ, Woll WJ, Baker EC (1986) Proteinase inhibitors in plant foods. In: Friedman M (ed), Nutritional and toxicological significance of enzyme inhibitors in foods. New York: Plenum Press, pp 299-310.

7. Sastry BN (1952) In: Wealth of India: A dictionary of Indian materials and industrial products. New Delhi, CSIR, Vol. III, pp 106-107.

8. Banarji AP, Kamala S (1969) Trypsin inhibitors from field bean: Isolation, purification and properties of a trypsin inhibitor from field bean. Enzymologia 36: 137-152.

9. Kamala S, Ambe AS (1955) Crystalline trypsin inhibitors form Indian field bean and double bean. Nature 175: 108-109.

10. Weeder JKP (1986) Inhibition of human proteinases by grain legumes. In: Friedman $M$ (ed), Nutritional and toxicological significance of enzyme inhibitors in foods New York: Plenum Press, pp 239-279.

11. Rayas-Duarte P, Kergeron D, Nielson SS (1992) Screening of heat stable trypsin inhibitors in red kidney beans and their partial purification from great northern beans. J Agric Food Chem 40: $32-42$.

12. Richardson M (1991) Storage proteins of plants. In: Dey PM, Harborne JB (eds), Methods in plant biochem, 5. New York: Academic Press, pp 259-309.

13. Veerabhadrappa PS, Manjunath NH, Virupaksha TK (1981) Proteinase inhibitors of finger millet. J Sci Food Agric 29: 353-358.

14. Kakade ML, Simson N, Liener IE (1969) The evaluation of synthetic substrates for measuring antitryptic activity in soybean samples. Cereal Chem 46: 518-526.

15. Kakade ML, Swenson DH, Liener IE (1970) Note on determination of chymotrypsin inhibitory activity using casein. Anal Biochem 33: 255-258.

16. Ramasarma PR, Rao R (1991) Nature of tryptic and chymotryptic inhibitors from horse gram. Indian J Biochem Biophys 28: 418-424.

17. Chadrashekar G, Raju DS, Pattabiraman TN (1982) Natural plant enzyme inhibitors: Proteinase inhibitors in millets. J Sci Food Agric 33: 447-450.

18. Ambe KS, Kamala S (1956) Studies on trypsin inhibitors in Indian food stuffs. J Sci Industr Res 15C: 136-139. 